\title{
RESEARCH
}

Open Access

\section{The potential for successful climate policy in National Energy and climate plans: highlighting key gaps and ways forward}

\author{
Keith Williges ${ }^{1 *}$ (D), Wytze Van der Gaast ${ }^{2 \dagger}$, Krisztina de Bruyn-Szendrei ${ }^{2 \dagger}$, Andreas Tuerk ${ }^{1,3}$ and Gabriel Bachner ${ }^{1}$
}

\begin{abstract}
Background: The EU "Winter Package" sets out specific energy and climate goals and urged formation of National Energy and Climate Plans (NECPs) by Member States for 2020 to 2030. Integrating scaled-up mitigation technologies within existing economic and social structures face numerous difficulties and require careful planning. While some options may be less suitable than others within a given country context, solutions exist to mitigate negative impacts and build local acceptance. We assess the resulting plans in the context of: (i) economic effects, the trade-offs arising from scaled-up technologies in terms of energy system- and macroeconomic effects; (ii) climate effectiveness, via assessment of carbon payback times of technologies, and (iii) social aspects, with a focus on identifying approaches for wider social adoption and acceptance of mitigation options. Assessment takes the form of case studies for Greece, Austria, and the Netherlands, three EU member states with very different preconditions.

Results: In terms of economic efficiency, NECPs lack consideration of the unique properties inherent in large-scale renewable energy deployment, and we suggest a possible way forward for future macroeconomic assessment via incorporating integration costs. For economic efficiency, we find that countries may be overestimating their contributions to GHG reduction targets via failure to incorporate life-cycle based analysis. Addressing feasibility, we find that countries address acceptance to different extents, with Greece and Austria holding stakeholder workshops and allowing for public comment on draft NECPs, while the Netherlands undertook a more extensive effort to ensure local public acceptance and involvement in planning.

Conclusions: The results illustrate that even though NECPs may be finalized, their success is far from ensured, and neglecting to consider key aspects of efficiency, effectiveness and feasibility may result in underestimation of impacts, failure to have as large an impact on GHG reduction as expected, or increasing public resistance to climate policies. We present approaches to deal with gaps in economic and environmental assessment, and highlight methods for improving public acceptance via examples from the case studies and related literature.
\end{abstract}

Keywords: EU climate policy, National Energy and climate plans, Computable general equilibrium, Carbon payback time, Social acceptance

\footnotetext{
* Correspondence: keith.williges@uni-graz.at

${ }^{\dagger}$ Wytze Van der Gaast and Krisztina de Bruyn-Szendrei contributed equally to

this work.

${ }^{1}$ Wegener Center for Climate and Global Change, University of Graz,

Brandhofgasse 5, A-8010 Graz, Austria

Full list of author information is available at the end of the article
}

(c) The Author(s). 2022 Open Access This article is licensed under a Creative Commons Attribution 4.0 International License, which permits use, sharing, adaptation, distribution and reproduction in any medium or format, as long as you give appropriate credit to the original author(s) and the source, provide a link to the Creative Commons licence, and indicate if changes were made. The images or other third party material in this article are included in the article's Creative Commons licence, unless indicated otherwise in a credit line to the material. If material is not included in the article's Creative Commons licence and your intended use is not permitted by statutory regulation or exceeds the permitted use, you will need to obtain permission directly from the copyright holder. To view a copy of this licence, visit http://creativecommons.org/licenses/by/4.0/. 


\section{Introduction}

Within the EU, the "Winter Package" introduced by the European Commission (EC) in November 2016 focused on clean energy, with steps towards increased energy efficiency, growth of renewable energy, and the reorganization of electricity markets in Europe to reduce energy poverty. It called upon Member States to formulate National Energy and Climate Plans (NECPs) [1], in line with the EU's Energy Union Strategy for 2030 [2], and national long-term low emission strategies for 2050 . The package aimed at being a substantial step towards reducing the EU's greenhouse gas (GHG) emissions by 40\% before 2030 - in line with EU pledges at COP-21 (held in Paris, December 2015) - and by 80 to $95 \%$ by 2050. While the energy and climate goals of the EU require scaling up of climate change mitigation technologies to high levels, integrating such options in existing economic and social structures requires careful planning and acknowledgement that measures need to fit country contexts, but also that solutions exist to mitigate potential negative side effects and build local support among citizens.

The NECP design process has recently (as of December $31^{\text {st }}$ 2019) been completed, after an iterative period of drafting and both public and EC review, and countries are now faced with implementing their pledged policy pathways to 2030. But how feasible are these plans, especially considering that some countries have most likely failed to meet climate goals for 2020? We attempt to answer this question using a holistic approach, synthesizing research focusing on three main facets of successful climate policy as defined in the literature: (i) economic efficiency, (ii) environmental effectiveness and (iii) feasibility [3]. To narrow our discussion, we focus on aspects of the NECPs related to the dimension of decarbonization, specifically the buildup of renewable energy capacity. Combining recent general equilibrium analysis of renewable electricity generation, life-cycle analysis of the time delay between implementation of renewable capacity and achieving carbon-neutral generation, and literature review relating to public acceptance of GHG reduction efforts, we assess the potential for success of countries' NECPs based on representative cases for Europe and suggest recommendations for policymakers as they begin the task of implementing their climate plans.

We address economic efficiency (i) in terms of costeffectiveness (if a policy can achieve its objectives at minimal cost) and distribution (how the costs and benefits of a policy are borne across society) and (ii) in macroeconomic terms via use of computable general equilibrium (CGE) modeling of large-scale buildup of renewable capacity, contrasting results with estimates of impacts from country NECPs. We focus on estimated changes in projected growth, wages, and welfare (the consumption possibilities of households) when considering the system-level costs (e.g. additional burden introduced by large portions of electricity generation from renewables due to their variable and intermittent nature).

Environmental effectiveness, the extent to which a policy meets intended environmental objectives [3] is discussed in terms of Carbon Payback Times (CPT), a measure which approximates how soon a technology's life-cycle emissions are offset by GHG emissions reduction [4]. As countries plan extensive buildup of renewable energy source (RES) capacity over the next 10 years, we attempt to identify the extent to which this new generation will be carbon-neutral, or if there may be overestimates of the GHG impacts in the NECPs.

Finally, we address feasibility in terms of political feasibility as defined in IPCC as the "likelihood of a policy gaining acceptance and being adopted and implemented" [3] via an overview of literature focusing on acceptance of RES buildup in our three cases.

We focus our analysis on three case study countries, (i) Greece, (ii) Austria and (iii) the Netherlands, representing different starting points regarding EU energy policy (discussed in further detail in the section "Selection of case studies and overview of their NECPs") in terms of varying economic considerations (such as the costs of financing new renewables generation), current shares of renewables in the energy consumption mix, and climatic conditions. It is important to underline that despite the broad categorization of the countries and their characteristics; the case studies will not result in blueprints for policy making on how to scale up technology options. Rather, the case studies demonstrate the impact of different country contexts and NECP 'starting points' on decisionmaking about mitigation technologies.

In the rest of this work, we first provide a background into the goals of the EU Winter Package, followed by an overview of our framework (in terms of the three facets of effective climate policy) and methodological approach, including the justification of our three country case studies. We then present results from case studies of Greece, Austria and the Netherlands, summarizing their NECP pledges and comparing their projections for the future with our three criteria, and finish with a discussion and recommendations for policymaking, and concluding remarks.

\section{Background}

\section{The winter package and NECPs}

NECPs were tasked with covering the key dimensions of the EU's Energy Union Strategy: decarbonization, energy efficiency, energy security, the internal energy market and innovation and competitiveness [1], while being in 
line with Member States' strategies towards lowemission economies by 2050. Important in the Winter Package was the envisaged role of stakeholders as actors in energy efficiency and renewable energy value chains and consumers of energy. The Package additionally recommended that (negative) societal impacts of the clean energy transition be minimized.

Determining the scale of deployment and diffusion of technology options for reaching the country's and the EU's energy and climate targets is an overarching challenge for policy makers. Partly, the scale depends on the technology's 'technical potential' for which, for instance, the availability of renewable energy resources such as biomass, wind, hydro and solar energy in the country is an important factor. To realize the strongest climate effectiveness, renewable energy technologies need to be deployed in areas or regions where most of the resources are, such as high wind speeds or high solar radiation, which are however often far away from actual demand centers.

Next to climate effectiveness, the scales for individual technologies within Member State may furthermore depend on economic and social drawbacks or benefits of a given technology. Some of these drawbacks can be measured by impacts on economic indicators such as gross domestic product (GDP), electricity prices, employment, wages and capital prices, etc. Deployment and diffusion of technologies for mitigation are expected to result in a range of positive impacts, such as newly created jobs [5] and increased added value in renewable technology installation. However, there may also be negative impacts, such as:

- Job losses and/or lower wages in sectors not benefiting from the deployment and diffusion of renewables [6];

- Higher energy costs for consumers due to increased electricity demand (e.g. due to electrification of industrial and transport sectors, along with continued economic growth and increasing standards of living [7]) in combination with required system-level improvements [8] (in this work, represented as "integration costs"); and

- Higher capital costs, as renewable energy technologies are more capital-intensive than conventional energy technologies [9], meaning that an increase in clean technologies requires large amounts of investments and thus capital [10].

This begs the question of how to scale up technologies for mitigation in the NECPs to a level that is politically affordable for policy makers from the perspective of socio-economic impacts, as they may be more concerned with shorter time frames than are necessary when thinking about long-term low-carbon transition.

With respect to climate effectiveness, it is important to consider that technologies for mitigation not only contribute to GHG emission reductions, thus reaching climate targets, but their production, construction, operation, and eventual dismantling also cause GHG emissions. Hence, the net mitigation impact of a technology is the difference between the emission reduction effect of replacing fossil fuel-based technologies and the life-cycle emissions.

This net impact is important to consider as several mitigation technologies are produced in Europe, while other life-cycle phases may not take place in Europe (or may take place in other Member States). This means that from a European perspective, not only are the emission reduction gains of mitigation technologies accounted for in climate inventories of Member States, but also in some cases the life-cycle emissions (albeit possibly in different Member States and different economic sectors).

From a production based emission accounting perspective, for overall EU climate change mitigation effectiveness, it thus makes sense that states include technologies in their NECPs with the shortest carbon payback time (CPT), a measure of how soon a technology's life-cycle emissions are offset by its contribution to GHG emission reduction [4]. While lifecycle emissions are not currently included in GHG accounting systems, they may be included at a later stage, and their early consideration can thus be beneficial.

\section{Three facets of successful policies Economic efficiency}

Criteria falling under the category of economic efficiency address the goal of having a policy achieve its objective with the least cost to society; for mitigation efforts, this is equated to achieving a goal at a minimum aggregate cost of abatement. Environmental taxes, for example, are believed to be very efficient instruments as they equalize marginal abatement costs across all economic actors, with actors which can reduce emission at lower costs reducing more than actors which face high emission reduction costs [11]. Various frameworks define the criteria differently, ranging from simply cost effectiveness [12] to further differentiation into static and $d y$ namic efficiency [13-16]. Static efficiency represents a policy functioning at least cost, given currently available abatement options, while dynamic efficiency allows for minimizing the cost of achieving targets over a given time period, thus assuming efforts to find cheaper abatement options and incorporating technological progress [17]. 


\section{Environmental effectiveness}

Effectiveness puts the actual effect of a policy at center. It measures the results of a policy intervention, either as an output of a policy (implementation of laws or regulations), an outcome (such as a share of renewables or the number of electric cars), or the impact of a policy, e.g. the level of climate impacts avoided [7]. It measures whether a policy or package is actually achieving the objectives it has set out to do; e.g. meeting a certain target of emission reductions. Taking again the example of an environmental tax, it might be very efficient, however, when set too low, may only be minimally environmentally effective.

\section{Feasibility}

For scaling up technologies for mitigation, it is important that they are compatible with existing social structures and can be readily accepted. This is an important aspect for determining the scale at which a technology option or the stringency of a policy can be realistically implemented [18]. The final broad criterion for policy success is thus feasibility, which speaks to the probability of success or conversely its risk of failure, and addresses risks that the policy may not be implemented as designed or may not produce expected results. Specifications of feasibility range from a focus on distributional effects and institutional feasibility [3], coherence with overarching policy objectives [19], to administrative simplicity and political acceptability [20]. Feasibility also speaks to normative criteria, highlighting equity and distributional effects (either relating to political acceptability, or more generally relating to public acceptance of a proposal). Again, an environmental tax is very efficient and might be very effective when set sufficiently high, however, faces the risk of failure due to low public acceptance; e.g. due to the fear of higher prices and lower purchasing power of households.

\section{Selection of case studies and overview of their NECPs}

As discussed in the "Introduction", this work assesses the projected deployment of mitigation technologies at large scales (as outlined in country NECPs) in three dimensions; (i) economic efficiency, (ii) environmental effectiveness, and (iii) feasibility on three case study countries. In the following section, we motivate the choice of case study countries, give descriptions of their characteristics and provide an overview of their NECPs with regard to buildup of RES.

To address different country contexts, the cases represent different starting points regarding EU energy policy and the goals of their NECPs, namely in terms of the costs of financing (or capital), current share of renewables in the energy mix, and climatic conditions. This broad categorization allows for a representative country case to highlight issues which may arise due to one or more factors and may serve as examples for other countries with similar starting points. To span a range of potential national situations in the EU, we utilize country case examples of Greece, Austria, and the Netherlands, which are discussed in detail below.

\section{Greece}

For several years, Greece has been in recession and under credit crunch conditions, with high interest rates and high costs of capital due to a high risk profile; due to these conditions, its WACC is assumed to be high relative to the rest of Europe, around 12\% [21]. It is characterized by a high share of fossil fuels in its electricity mix; $18 \%$ of primary energy supply ( $26 \%$ of electricity generation) was derived from renewables in 2018, mainly by wind and solar PV [22].

In its final NECP [23], Greece aims to increase its renewables as a share of gross final energy consumption to at least $35 \%$ by 2030 , with an equivalent share in final consumption of electricity of $61 \%$, mainly via the buildup of wind (from 7.3 TWh in 2020 to 17.2 by 2030) and solar PV (4.5 TWh in 2020 to 11.8 in 2030). Greece also anticipates the electrification and coupling of final consumption sectors, e.g. transportation via full electrification of railways, housing via use of heat pumps, and other sectors using energy storage systems, among other strategies. Challenges include the existing institutional framework, which lacks clear rules and criteria for planning of RES development, coordination between institutions, a market model which adequately addresses the needs and issues of RES, and a desire to develop RES projects with local value-added.

The impact of RES and energy efficiency plans are estimated via use of partial equilibrium economic modeling (the TIMES and PRIMES models), which are limited in their ability to assess effects of changes in e.g. the electricity sector (in terms of prices or quantities of electricity produced) on other sectors and final demand. The plan provides estimates of e.g. domestic added value (12 billion EUR due to new investment in RES) projected additional employment (37 thousand full timeequivalent jobs for ten years) and incomes (4.8 billion EUR over the lifetime of projects) [23]. The plan notes that the goal of RES penetration is achieved most costeffectively for the national economy via significant increases in wind and PV due to their high capacity factors and thus low weighted cost of electricity production in the short run and due to being directly competitive with conventional generation in the electricity market. However, these estimates may not be based on models which incorporate unique aspects of RES generation and the resulting additional costs, thus possibly leading to underestimation of resulting economic effects. 
The NECP of Greece has been strongly criticized by the EC. It is vague regarding feasibility and incorporation of public and stakeholder views; in its review of the draft document submitted in January 2019, the EC found that while the plan mentions the need for a "just and fair transition" via a Fair Transition Support Initiative there is little elaboration of specific projects, support and impact of such an effort. The final NECP does not elaborate broadly on this point, and regarding stakeholder dialogue notes a period of public consultation, without identifying any conclusions from such and/or how they have been incorporated into the final plan [24].

\section{Austria}

Austria was selected to provide an example of a country with a high renewable share of total electricity generation, which as a result has enabled the country to be on track to meet or exceed its EU energy and climate mitigation targets. Hydropower has long held the lion's share in terms of electricity production, and in total in 2018, the renewables share of electricity production stood at $73 \%$ [25], with the residual produced by fossil fuel sources, e.g., natural gas and coal. Beyond the electricity sector, Austria has low interest rates, with a weighted average costs of capital (WACC) estimated at 6.5\% [21].

Austria's NECP [26] defines the target pathway for RES in total final energy consumption as rising from $34 \%$ in 2020 to between 46 to $50 \%$ by 2030 , with $100 \%$ of total electricity to be generated by domestic RES in 2030. The country anticipates wind power rising from 8.6 TWh in 2020 to 16.7 in 2030, with PV increasing from $3.6 \mathrm{TWh}$ to 11.7 by 2030 . This corresponds to a share of final energy demand for wind of $6.7 \%$ in 2020 to $10.6 \%$ in 2030 , and for PV of $2.8 \%$ in 2020 to $7.5 \%$ in 2030. Hydropower, currently the dominant form of electricity generation, will remain relatively stable over the same period, but will be reduced in share of final energy consumption from 34 to $28 \%$ by 2030 . Austria also notes the need to address balancing, flexibility of networks, and ensuring the security of supply due to the introduction of more RES capacity, and anticipates greater electrification of the transport sector via e-mobility, and reduction of remaining emissions via use of bioethanol and biodiesel in transport (along with encouraging or mandating the use of e-mobility options via phasing out combustion engines from 2030 and beyond).

Also Austria's NECP has been criticized by the EC [27], as well as by Austrian scientists [28]. It is comparatively vague with regard to the broader economic effects of the planned measures, with only cursory examination of possible changes to GDP growth (from 2.0\% in 2020 to $1.5 \%$ by 2030 , remaining steady to 2040 ). Most impact estimates focus on the changes due to existing measures on the energy mix and sectoral demands. Additional analysis from the Federal Environment Agency is referenced, but not elaborated upon.

In terms of feasibility and social acceptance, the plan outlines various consultations of e.g. ministries, federal states, social partners (e.g. agricultural, labor, trade union confederations), associations of industries, cities and municipalities, and representatives of science. Most interaction involved round-table events and online consultations, with a public review period of the draft NECP with the ability to submit concerns by members of the general public. However, little elaboration is provided as to the nature and manner of addressing any concerns which arose.

\section{The Netherlands}

The Netherlands provides a contrast to the other two cases. Similar to Austria, it is country with strong financial conditions; it is assumed to have a WACC in line with other western European countries, around 5.3\% [21], but it shows a much lower share of RES in total current energy consumption. While prior to the NECP policy process, the country had a 2020 goal of having $14 \%$ of all energy consumed produced from renewable energy sources [29], which it was not predicted to meet, with the latest estimates for 2020 expected RES share of $11.4 \%$ [30].

Considering its relatively low RES starting point, in its NECP the Netherlands has outlined an ambitious plan to boost the share of RES in total energy supply to $26 \%$ by 2030 , with its share in total electricity production in 2030 predicted to be $70 \%$. The rise would be made up predominately of offshore wind (49 TWh by 2030), onshore wind and large solar PV parks ( 35 TWh by 2030) and small-scale RES e.g. rooftop solar making up 10 TWh. In concert with the other two cases, the country highlights the need for flexibility via new market mechanisms to address the intermittency and lack of dispatchability issues presented by having a large portion of RES [30].

The plan makes use of both CGE (the WorldScan model) and macro-econometric (SAFFIER model from the Dutch Ministry) modeling to estimate effects on the broader economy, finding that new policies are likely to result in GDP falling $0.5 \%$ below baseline scenarios by 2030. Incomes are expected to increase with the introduction of proposed policies, with positive income effects foreseen at $0.3 \%$ in 2030 , but not equally distributed over income classes, with lower incomes seeing rises of $0.7 \%$, and higher incomes only $0.2 \%$ [30].

In contrast to the other cases, the Netherlands outlined an extensive approach to dealing with social acceptance, which was noted already in a review of the draft version by the EC [31]. In line with the other cases, 
the plan was open to public consultation for a period of 6 weeks, with additional stakeholder consultation and discussions. Additionally, the Netherlands took a municipal-focused approach to renewable electricity generation, emphasizing the need for a participatory approach for energy projects, providing tools and guidelines for such for developers, governments and financiers. The plan sets a goal to have $50 \%$ local ownership of electricity production in the local environment (e.g. local citizens and businesses) by 2030. The Social and Cultural Planning Office also runs a "Sustainable Society" program, providing a socio-cultural perspective on the transition to sustainable society, research on the relationship between citizens and the government in the context of transition, and impacts of transitions on quality of life.

\section{Open issues from NECPs \\ Lack of consideration of integration costs}

The three cases use varying approaches to assess the economic efficiency of their climate packages. Austria's assessment was cursory, focused mainly on changing shares of production in the energy mix and sectoral demand, while Greece utilized partial equilibrium models to produce forecasts of changes in sectoral use of energy and macroeconomic estimates of changes to e.g. agricultural, mining, and industrial sectors due to changing energy sources and costs. The Netherlands produced the most comprehensive macro assessment via both CGE and macro-econometric modeling ${ }^{1}$, and provided explicit assessment of the possible macroeconomic and distributional effects of the planned policy package.

However, a key component for achieving these GHG emission reductions is via drastically upscaling the use of RES, which differs from conventional generation due to its intermittency and lack of dispatchability. These differences make it difficult to compare costs of electricity across generation type (typically described using levelized cost of electricity (LCOE) [33], an easy way to assess what each unit of electricity would need to cost to repay investments and maintain the plant). Scaling up a technology with intermittent generation within a country will require additional investments in, e.g., grid, balancing and system integration activities. These system integration costs arise after production of electricity at a

\footnotetext{
${ }^{1}$ The alternative approaches, strengths and weaknesses of CGE versus macro-econometric models are beyond the scope of this work, but extensive overviews can be found (e.g. Pollitt et al. [32]) Generally, CGE models represent cases of optimization assuming perfect knowledge, whereas macro-econometric models can incorporate uncertainty; CGE models assess how optimal resource use may change, given a policy constraint, while macro-econometric models allow for assessing impacts of using more or less of available resources.
}

generation site, when that power is supplied to the larger grid. As described by Hirth et al. [8], they include:

- balancing costs, which occur due to deviation from day-ahead planned generation schedules, requiring overcapacities or capacity reservations of thermal power plants.

- grid-related costs, the reduction in market value due to the location of generation in the power grid, which might be far away from demand centers; essentially, the marginal costs of transmission losses or limitations.

- profile costs which arise because the supply of renewables does not follow load profiles from demand (e.g. seasonality of PV). Thus, demand gaps must be handled by dispatchable plants at some point. However, with more RES the full load hours of the dispatchable plants are reduced (as they only produce when RES do not), leading to efficiency losses and eventually to higher LCOEs for these plants; which is the so called "utilization effect." On the other hand, RES may at times exceed demand, leading to an oversupply of electricity.

Until recently, RES expansion scenarios in macroeconomic modeling did not take into account these integration costs, and as such, the evaluations in the NECPs may be underestimating the impacts of large-scale increases.

\section{No consideration of life-cycle emissions}

None of the cases explicitly address environmental effectiveness of their plans, which is not unreasonable; as environmental effectiveness is typically measured as e.g. a share of renewables in the final energy mix, NECPs which meet the EU climate goals can be considered to fulfill the criteria. However, as discussed in the section on "The winter package and NECPs", life-cycle emissions have an eventual impact on the time at which a renewable installation affects an emission reduction. In this sense, NECPs may be overstating the emission reductions from RES installation, as substantial capacity buildup is planned for later in the decade.

\section{Varying degree of feasibility assessment}

While each case NECP stated its process for inclusion of stakeholders and the general public in formulation of their plans, they did so to different degrees, with the EU in its review noting that certain countries were lacking in this regard, while others appeared to make a more concerted and substantive effort. However, none of the NECPs note the degree to which public or stakeholder input changed the planning process, nor how plans took various public views into account. Thus, the question of 
how well the NECPs correspond to public wishes and opinion remains open.

\section{Addressing gaps in the NECPs - methodological approach}

With the points from the "Open issues from NECPs" section in mind, we attempt to provide examples of how these issues can be addressed as Member States proceed forward with NECP implementation. Synthesizing research which addresses these knowledge gaps and potential barriers to success, we bring together emerging work on integration costs in macroeconomic modeling and carbon payback times. We additionally compare NECP proposals and social acceptance strategies to literature on feasibility for the cases, to present a holistic view of the NECPs and highlight possible issues in the future as implementation begins.

\section{Economic efficiency}

The case country NECPs addressed macroeconomic effects of their plans to varying degrees, but do not explicitly take into account the additional costs due to the integration of large amounts of RES into the electricity system. However, efforts to incorporate these considerations into economic models have been undertaken, and we use the results of two CGE models to identify the extent to which these integration costs may skew assessments of e.g. future costs of electricity, GDP, and welfare.

CGE models allow for a modeled microeconomic representation of market interactions and assess the likely change in sectoral activity and macroeconomic indicators due to a simulated change such as a policy implementation, and allows for representing the interlinkages between markets, where changes in supply and demand in one market are linked to price changes in other markets [34]. CGE models generally consist of a representative household (or households) which provide factors of production (labor and capital). This household receives income from factor earnings, plus government transfers. Income is used to maximize utility, by spending it for consumption of goods and services which are produced by multiple production sectors. By measuring the change in consumed quantities, we obtain a welfare effect ${ }^{2}$. Production sectors use the factors of production plus intermediate inputs (i.e. output from other sectors) to produce output and seek to minimize production costs. This behavior of households and producers is assumed to ultimately lead to a flow equilibrium in which all markets are cleared (i.e. supply $=$ demand for all goods and services), also called "benchmark equilibrium."

\footnotetext{
${ }^{2}$ The so called Hicksian Equivalent Variation, or the willingness to pay (accept) for a price rise (fall) not to occur
}

Policies are modelled in CGE approaches by shocking a benchmark equilibrium via a policy introduction, which leads to responses of consumers and producers via their optimizing behavior under these new conditions, resulting in a new equilibrium state composed of a changed matrix of demanded quantities and prices of goods. Such models allow for showing how changes in quantities or prices in one sector affects other sectors, final demand, and macroeconomic indicators e.g. GDP and welfare, or the consumption possibilities of households. CGE models can be comparative-static, comparing reactions in an economy at one point in time, or dynamic, incorporating assumptions of future changes for exogenous variables and representing possible changes over time.

We use two CGE models, one comparative-static, and one recursive-dynamic, both multi-regional and multisectoral, to compare the potential impacts of integration costs on macroeconomic assessments of NECP policies. For the cases of Greece and Austria, a static model based on the GTAP9 database (Aguiar et al. [35]) was used to illustrate the impacts of a large-scale expansion in RES technologies by 2030 in Europe (for a more extensive model description, see Bachner et al. [21]). The model applies scenarios on wind energy buildup for European regions and for Austria and Greece explicitly, which project wind penetration in Austria to be a $23 \%$ share of total electricity generation, and $40 \%$ in Greece. For a scenario of scaled-up PV, Austria is modeled as having $38 \%$ PV penetration, and Greece $66 \%$. While these scenarios cannot directly be used to assess likely impacts of the NECP policies, due to differences in cost estimates and RES penetrations - the Austrian NECP would result in wind penetration of approximately $20 \%$, and PV of $14 \%$, and the Greek NECP a wind penetration of $36 \%$ and PV of $25 \%$, thus the scenarios from [21] would for PV be large overestimates, less so for wind - they can serve to demonstrate the impact of incorporating integration costs into such analysis. Comparing scenarios with and without integration costs can provide an indication of the degree to which conventional macro analysis is under/overestimating impacts. Integration costs are incorporated by inclusion of the utilization effect portion of profile costs, as well as grid-related costs. The utilization effect is modelled via requiring more capital input for each unit of output from the residual electricity sector (15 EUR/MWh) [36], while grid related costs are incorporated via increased investment costs of wind and PV (an additional $150 \mathrm{EUR} / \mathrm{kW}$ for both technologies, based on estimates from the literature $[8,37,38]$ ).

For the Netherlands, we take a similar approach of comparing scenarios with/without the effects of integration of RES, but here using a dynamic-recursive model (as the model of Bachner does not explicitly model this 
country separately). However, recent work from Mayer et al. [39] builds on the model from Bachner, which is also multi-regional and multi-sectoral, but in this case solves in 5-year time steps to 2050. A full description of the model can be found in Mayer et al. [40] and Bachner et al. [41] The model compares a baseline scenario where in 2050, 66\% of electricity generation is via wind (on-shore: $\sim 51 \%$ and off-shore $\sim 15 \%$ )) and $15 \%$ from solar PV (both large-scale and rooftop), with a scenario closer to the case's NECP, with wind making up about $54 \%$ (on-shore: $\sim 15 \%$ and off-shore $\sim 39 \%$ ) and solar PV $33 \%$. This aligns partially with the 2030 projection from the plan, which estimates approximately $36 \%$ of production from offshore wind, $26 \%$ from onshore wind and large-scale solar, and 7\% from rooftop solar.

The comparison of an offshore-wind-intensive baseline with a counterfactual scenario comprised of more onshore wind and PV (and thus more intermittency) allows for observation of the effect of integration costs on scenario outcomes.

Mayer et al. [39] estimate the additional costs of renewables in terms of higher connection costs (e.g. for offshore wind, costs of both undersea cable to the shoreline, and additional costs from improving the country's grid capacity to handle the large influx of power from offshore) and investments in battery storage to address balancing costs. Offshore wind entails additional connection costs of $930,000 \mathrm{EUR} / \mathrm{MW}$ to run cable to the shore, and an additional 930,000 EUR/MW to improve the existing grid; on-shore wind and PV parks are estimated to result in additional connection costs of 81,000 EUR/MW, with similar additional costs to improve the existing grid. For battery storage, capacity requirements vary based on the share of electricity generation, and are installed at an increasing percentage of total demand for scenarios with over $25 \%$ of electricity from intermittent RES. Costs are estimated to drop (due to technological progress and learning rates) from $540 \mathrm{EUR} / \mathrm{kW}$ from the start of the scenario to $90 \mathrm{EUR} / \mathrm{kW}$ by the end in 2050 .

This dynamic depiction of an RES-intensive electricity system compares a baseline of mainly offshore wind (and thus, much less need for battery storage) with a system where intermittent generation rises above $30 \%$, thus necessitating large investments in batteries to solve balancing issues. This comparison illustrates the impact of more intermittent RES vs. less, but also allows for illustrating how those effects propagate over time.

\section{Environmental effectiveness}

As an indicator of the time needed for RES capacity to become net carbon neutral for our case countries, we use research defining a Carbon Payback Time [4] (CPT, also referred to as greenhouse gas payback time (GPT) in the literature) to judge environmental effectiveness.
CPTs vary by location and technology; for example, the lowest CPTs have been found for wind farms located offshore and near the coast, while it takes more time for wind power plants to recover their own life-cycle emissions when built onshore [42], due to by offshore turbines being taller so that they can endure stronger wind speeds.

As the NECPs employ significant buildup of RES over the next decade, based on the location-specific CPTs some of this new RES may not be actively contributing to reducing GHG emissions from the country, as it would still in effect be working off its own GHG debt from transport and installation.

Based on literature estimates of location- and technology-specific CPTs we estimate the amount of new capacity which would not yet be net-carbon-neutral by 2030, using projected new capacity from the case NECPs, identifying the possible degree to which countries may be overstating their GHG emissions as a result.

\section{Feasibility}

While an exhaustive and comparative analysis of feasibility and public acceptance is beyond the scope of this work, we use results from recent work focusing on the case countries to determine how closely the NECPs take into account reported public opinion, e.g. if decisions made on the size and rate of RES scale-up in the NECPs may encounter barriers to implementation due to differing public acceptance.

We do this via an analysis of the relevant literature, acknowledging that we may not include all related literature, but have focused on recent contributions focusing on public acceptance of RES. This overview is meant to provide examples of areas where policymakers will undoubtedly need to focus in the coming implementation period in order to meet NECP targets.

\section{Results}

In line with the open questions raised by the review of our case NECPs, we discuss below how increasing the share of renewables in electricity generation would affect the larger economy, emphasizing the effect of system costs on projected results. We then discuss the challenge of choosing locations and types of renewable energy sources to scale up in terms of life-cycle accounting and carbon payback times. Finally, we discuss issues of public acceptance or resistance to such possible policies.

\section{Efficiency: including integration costs in economic analysis \\ Greece}

While wind generation would be competitive by 2030 for most of Europe under a large-expansion scenario, the high WACC for Greece, combined with the 
inclusion of system costs, would lead to wind being noncompetitive (relative to the current average electricity production costs). The current electricity mix' LCOE is estimated to be just over $0.08 € / \mathrm{kWh}$, while the cost of wind power in a 2030 scenario including additional grid related costs would be over $0.09 € / \mathrm{kWh}$, as additional grid investment is attributed to the renewable part of the electricity system.

With grid-related portion of system costs included, the costs for electricity in 2030 would rise by 1 cent, to 0.09 $€ / \mathrm{kWh}$. In addition, the "utilization effect" drives up overall system costs (the use of more renewables means that conventional plants would be used less efficiently, leading them to increase their prices to recoup investments). However, a low-WACC scenario (representing a potential de-risking of investment [43-45]) could result in generation costs falling to competitive levels, even when including integration costs.

The results change for the solar PV expansion scenario, which is much larger in terms of final share of the total electricity supply. In a high WACC scenario including system costs (grid related), electricity from PV would still be over $0.015 € / \mathrm{kWh}$ cheaper than the current electricity mix' average cost. It should be noted that scenario assumptions are more indicative of large-scale installations, and costs may increase if a more rooftop-solar-oriented build-up of PV is undertaken.

Factor market effects within the model are represented as prices of labor and capital. With renewables expansion, the demand for capital increases, raising its price (i.e. capital rents), while the labor price (wage) decreases due to less demand (see Fig. 1. While higher capital rents and lower wages are seen in all EU regions, the strongest effects emerge in Greece, with up to + 9\% capital rent increases and reductions in wages for unskilled labor of $-7 \%$. The inclusion of integration costs into the analysis has sharply negative effects on wages for skilled and unskilled labor - particularly for a scenario with large-scale PV production - and lower forecasted GDP and welfare (w.r.t benchmark). The impacts on a wind scenario are less extensive than PV, but still emphasize that analysis without incorporating integration costs may be misconstruing possible economic impacts in the future.

The relatively strong effects in Greece are due to a higher capital cost share (due to high WACC) and due to ambitious scenario renewable technology penetration targets. When comparing across technologies, we see that PV triggers stronger effects since it is even more capital intensive than wind. For PV, capital rents increase by up to $+9 \%$ and wages decline by up to $-7 \% . \%$;

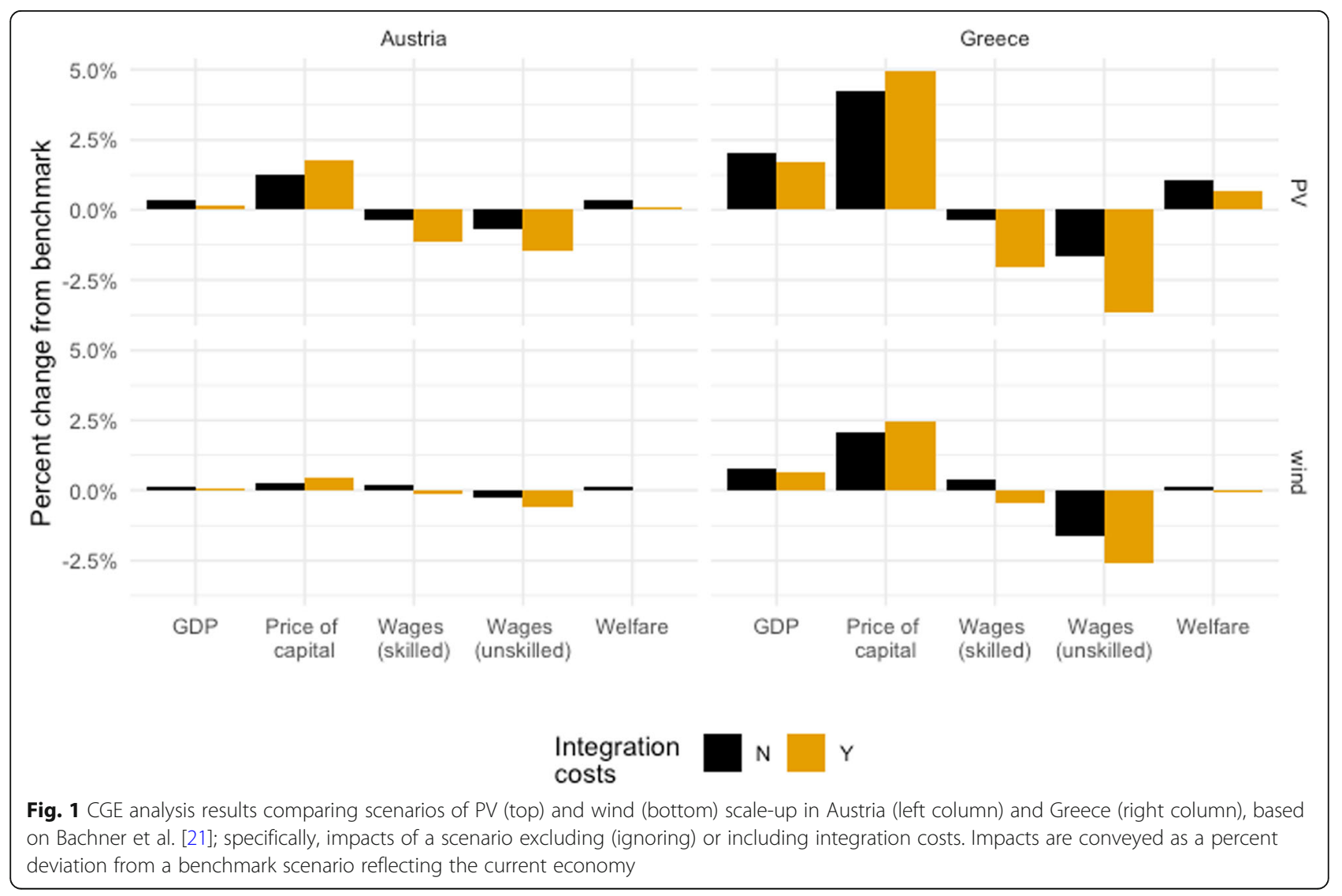


For wind, the maximum increase in capital rent is $+3 \%$ and the strongest decline in wages is $-3 \%$. When system integration costs are included, the effects on factor prices are slightly stronger, since the utilization effect additionally drives up capital prices.

While results from [10] presume that economy-wide effects (in terms of GDP) would be positive for Greece in both scenarios, welfare would only see a positive change in the PV scenario, with inclusion of integration costs resulting in a negative welfare effects in the wind scenario. The difference between GDP and welfare effects can be explained by price effects, which are included in GDP, but not in Welfare (e.g. higher relative prices would be reflected also as a higher GDP, but not in a higher Welfare level, which measures consumption quantities). However, if Greece could lower its WACC, this would result in an eventual positive welfare effect for both scenarios.

\section{Austria}

Similar to the Greek case, the inclusion of system integration costs (grid related) related to wind power expansion would result in a cost (LCOE) increase of almost $0.0080075 € / \mathrm{kWh}$ compared to the current electricity mix. This would result in an increase in the market price for electricity in Austria, due to the low current LCOE (as a result of the high share of hydropower) for its electricity mix in absolute terms $(0.06 € / \mathrm{kWh})$. However, sufficiently lowering WACC due to de-risking of investments would lead to wind LCOE being lower than the conventional mix, but only if system integration costs are not considered.

In comparison to wind power, the solar PV expansion scenario would result in competitive PV in the country, with an LCOE of about one tenth of a cent lower than the current electricity mix, but in terms of economywide effects and the market price of electricity, the eventual price would still be higher in 2030 than the current benchmark estimate by about $1 \%$. This is again due to the current LCOE being relatively low, producing an unfavorable cost ratio between $\mathrm{PV}$ and conventional generation.

In terms of follow-on effects, sectors are affected by a decrease in the production of electricity (sector activity falls $7 \%$ ) and corresponding increase in price (rising $2.2 \%)$, due to the results of higher electricity costs. The outlook is similar for PV expansion: electricity sector activity falls (by 6.8\%) and the price of electricity rises (by $2.5 \%)$.

While both the wind power and solar PV scenarios would increase capital rents (by 0.75 and $2.2 \%$ respectively) and reduce wages ( 0.5 and $1.25 \%$ respectively), the effects on GDP are positive for the country. However, with a scenario of high WACC and system integration costs, overall welfare is projected to be below the benchmark level, albeit minimally $(\sim 0.1 \%)$ in both scenarios, as neither technology can compete with the conventional mix. Even lowering WACC via de-risking would not produce positive welfare effects.

Compared to the Greek case, the inclusion of integration costs does not change results as drastically, although (as seen in Fig. 1) it does lead to further reductions in wages for both skilled and unskilled labor compared to the benchmark scenario (in line with Greece), higher costs of capital, and lower GDP and welfare, again with more prominent effects under a PV scale-up scenario.

\section{Netherlands}

While the Greek and Austrian cases demonstrate the impact of integration costs on static macroeconomic analyses, the work of Mayer et al. [39] show how such costs affect outcomes in a dynamic framework. As can be expected by switching from a baseline scenario with mainly offshore wind to a scenario with 33\% PV (requiring substantial investment in batteries to address intermittency issues), average electricity generation costs rise between 2 and 4\% over a period of 10-16 years, depending on cost and learning rate (e.g. how much costs decline per doubling in production capacity) assumptions, compared to the benchmark. However, due to the required investments for battery storage consumption is being reduced and therefore also demand for electricity. Thus, its retail price drops below the baseline scenario price by 10 years into the simulation.

In terms of macroeconomic effects, Mayer et al. [39] initially show a substantial drop in GDP over the first 10 years of the scenario, being lower by as much as $0.5 \%$ compared to the baseline, $\%$, before the lower generation costs for electricity results in rising GDP, with an overall net positive effect on GDP as compared to the baseline. The same trend holds true for welfare, although to a different degree, being lower in the first 10 years by $1 \%$ (compared to the baseline),\%, but being higher 5 years later by around $0.5 \%$ above baseline and maintaining that level until the scenario concludes.

\section{Estimating the potential for missed GHG reductions via carbon payback times \\ Greece}

As concerns wind power, estimates of country-specific CPTs for Greece are supplied by Abeliotis and Pactiti [42], with an estimate payback time of seven months. This falls well within the range of estimates for wind turbines in Northwest Europe of 2.2 to 8.8 months [4]. As Greece has relatively high solar insolation, PV capacity factors are higher than elsewhere in Europe. This leads to relatively short payback times: 1.62 years 
for Greece, compared to, e.g., Germany (3.54) and progressively higher CPTs as latitude increases [4]. However, there are some caveats. First, it pertains mainly to larger installations, with a reference plant of $570 \mathrm{~kW}$, employing over 4000 square meters of panels [4]. Second, it has been shown that high PV module temperatures in warmer climates limit their efficiency somewhat, with a comparative study between Germany and Cyprus showing a performance decrease of $4 \%$ in the southern country [47]. Thus, any estimate of CPT for smaller-scale PV generation in Greece (e.g., rooftop solar) may rather be a lower bound or first-order estimate.

Given the short payback times for wind in Greece, the vast majority of new capacity (as shown in Fig. 2) will be net carbon-neutral by 2030; assuming new production comes online evenly throughout the year, only 0.62 TWh of wind power would be 'younger' than its CPT. The slightly longer CPT for PV lead to 1.134 TWh of production not being carbon neutral, although again this should be viewed as an optimistic case, and in reality, given smaller e.g. rooftop plant sizes and loss of efficiency due to higher ambient temperatures, the CPT may be longer. In total, a first estimate of RES production contributing to GHG reduction goals in the NECP, but not being net neutral in actuality, is $1.756 \mathrm{TWh}$.

\section{Austria}

In terms of the CPT of wind in Austria, a comparison of its wind climatology versus the study area in Loriaux et al. indicates less favourable wind conditions for most of the country than northern European regions, which consistently see mean wind speeds of $6 \mathrm{~m} / \mathrm{s}$ and above (especially offshore wind, with averages of mainly $9 \mathrm{~m}$ per second $(\mathrm{m} / \mathrm{s})$ or higher) [4], while Austria averages wind speeds of $6 \mathrm{~m} / \mathrm{s}$ and below, and a power density (depicted as watts per square meter, $\mathrm{W} / \mathrm{m}^{2}$ ) of $200 \mathrm{~W} /$ $\mathrm{m}^{2}$ or less in the majority of the country [48]. Thus, while no concrete estimates can be derived as to the actual CPT for the country, wind turbines in Austria can be assumed to have substantially higher CPTs than those found for the region of North-western Europe.

For Austria a CPT for solar PV was estimated to be 9.64 years [4]. Austria's very high hydropower capacity results in its electricity grid's carbon footprint being relatively low $\left(0.21 \mathrm{~kg} \mathrm{CO}_{2} / \mathrm{kWh}\right)$, which raises the countryspecific CPT. Due to the low carbon intensity of Austria's energy market (large hydro-power share), more time is needed in Austria for Solar PV's emission reduction to be large enough to outweigh the technology's life-cycle emissions. This long CPT results in approximately $8.59 \mathrm{TWh}$ of production contributing to GHG in the Austrian NECP, while in reality not being carbon neutral. The lack of CPT for wind installations makes

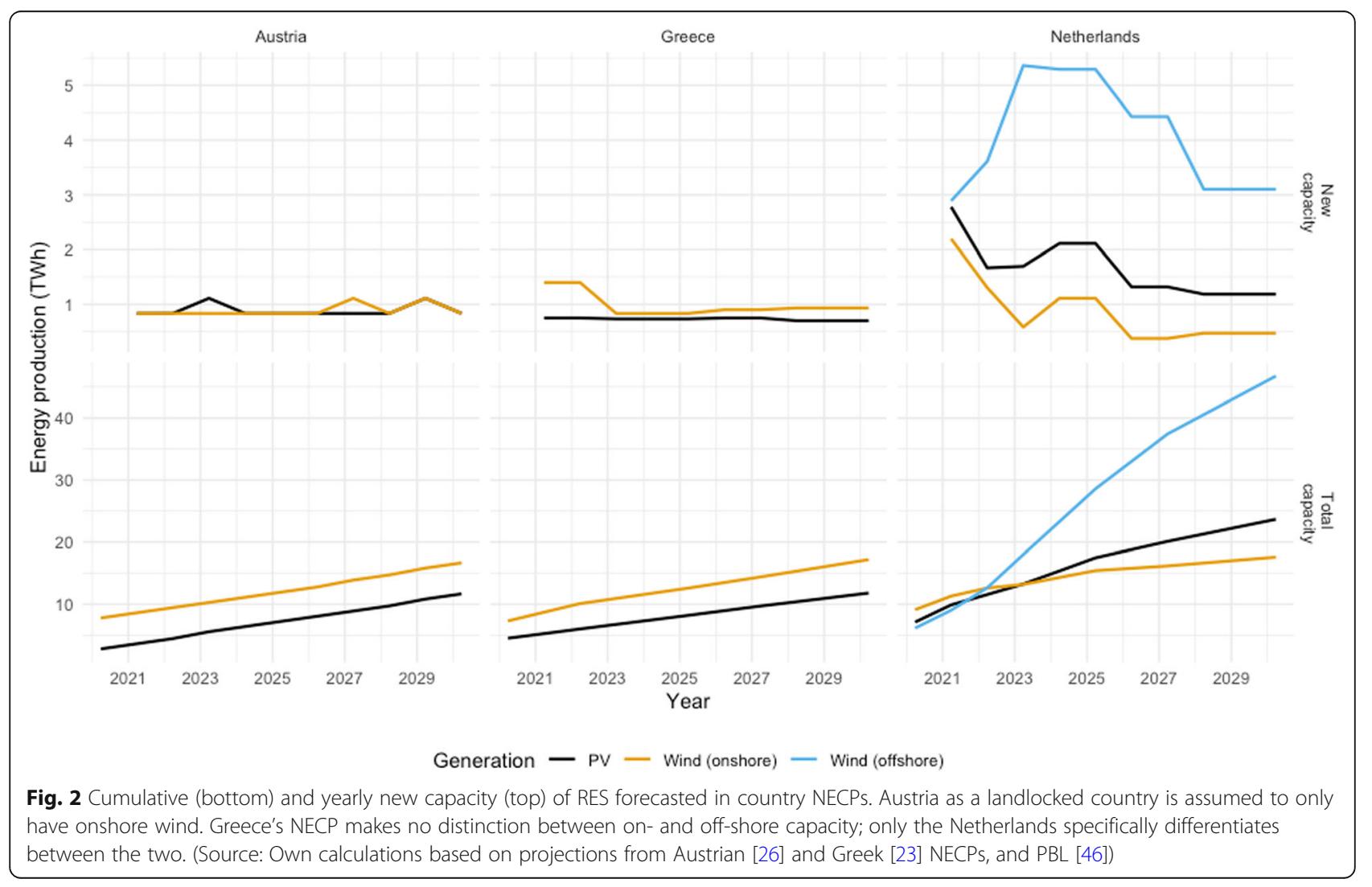


equivalent calculations unreasonable, but it is safe to assume lower payback times implying at least the final year or two of installations would not have reached carbon neutrality.

\section{The Netherlands}

The Netherlands was the only case country to differentiate between on- and off-shore wind production in their NECP, with the bulk of new RES buildup to come from offshore installations. Loriaux et al. [4] estimate the CPTs for wind plants in northwest Europe, specifically offshore and coastal areas, but does not provide separate estimates for CPTs for the two. Instead, a range of estimates are provided, with CPT varying between 2.2 and 8.8 months, with an average of 4 months. We assume offshore wind to have a CPT at the lower bound, and onshore the upper. The country-specific CPT for solar $\mathrm{PV}$ installations as is 4.41 years [4].

These CPTs result in only 0.92 of $49.1 \mathrm{TWh}$ of new wind installations not being carbon neutral. New wind installations are planned mainly earlier in the decade, and the extremely short CPT implies they quickly become net neutral. PV is another matter, however as the majority of PV scaleup is projected to take place early in the decade (see Fig. 2), only a relatively small amount of total PV will be installed in the last 4.4 years of the decade, with $5.42 \mathrm{TWh}$ of production not having reached its CPT, resulting in a country total of $6.33 \mathrm{TWh}$ being counted towards GHG reduction goals, while in reality not being net-neutral.

\section{Potential feasibility barriers \\ Greece}

As Fig. 2 illustrates, both wind and PV are expected to grow almost linearly over the next decade, with wind having an initially higher capacity buildup for the first two years (1.4 TWh per year from 2020 to 2022, as compared to 0.75 per year of PV), and subsequently adding only slightly more production than PV per year. Wind rises from 7.3 to $17.2 \mathrm{TWh}$, while $\mathrm{PV}$ increases from 4.5 to 11.8 ;

A survey of literature dealing with social acceptance and public opinion of wind power in the country finds a general preference for PV over wind power, which could present issues with the planned early scaleup of wind. Previous work has found that while $78 \%$ of the population perceives wind energy as beneficial and almost twothirds of the population supports existing infrastructure [49], a huge gap appears in terms of support of future wind development, with only $35 \%$ of the population in favor, and $21 \%$ finding them aesthetically displeasing. Further work highlights that residents in areas with wind turbines generally supported expansion of capacity, but not in their own region [50], possibly due to fears of negative impacts on tourism [14] or a Not-In-My-Backyard (NIMBY) response. Comparatively, public opinion for expansion of solar PV installation is seen as more positive [51], with surveys by [52] showing that $94 \%$ of respondents were in favor of PV parks. Over half of respondents indicated that there were no visual impacts from such installations, and $22 \%$ stating that they were an annoyance.

\section{Austria}

Like Greece, Austria plans relatively linear development of both its wind and PV resources, forecasting for both technologies a rise of 0.833 TWh per year. While Austria does not extensively outline measures to ensure public agreement with its RES buildup, by-and-large, the country has not experienced much difficulty in terms of social acceptance in the past, having an extremely high portion of electricity from hydropower, however, further expansion of hydropower has started to target ecologically sensitive areas, with increasing public resistance [53]. Walter \& Gutscher [54] highlight frequent and early public interaction as a key factor in dealing with and solving public opposition to renewables development. This, in addition to political support at all levels of government, is viewed as the reason for Austria's success in diffusion of renewable energy resources.

A counter example to the successful development of renewable energy sources is Austria's lack of success at introducing demand-side measures to reduce emissions, namely in the building sector. While renewable energy sources enjoy broad support across all political levels, the structure and division of responsibilities of Austria's national and state-level authorities (building policies are decentralized, with responsibilities mostly falling to regional governments) led to provinces failing to meet EU requirements on building energy performance [55].

\section{The Netherlands}

As a juxtaposition to the other cases, the Netherlands NECP proposes larger increases in RES, heavily reliant on wind power. The plan placed emphasis on involvement of local and national stakeholders in participatory processes, and a focus on local / municipal level planning, to improve public acceptance, and set a target of $50 \%$ local ownership in RES installations by the end of the decade.

The plan's objectives in terms of social acceptance are backed up by observations in the literature, particularly in regard to emphasis on local ownership, rather than relying on new RES for jobs as economic incentive. In general, expansion of the solar energy sector leads to increases in employment, but these gains may be fleeting. Koning, Smit \& Dril [56] and Ligtvoet, Pickles \& Barneveld [57] conclude that most jobs in the solar PV sector 
in the Netherlands are generated during the construction phase for both rooftop and large-scale projects, with short term and flexible terms of appointment. Jobs for operation and maintenance of ground-mounted solar parks are more long-term, but their number is relatively small. According to Koning et al. [56], around 9165 work years of employment will be generated in the period of 2014-2020 for $985 \mathrm{MW}$ of solar panels, with a resulting ratio of full-time equivalent work per megawatt of 9.3 .

At the same time, job losses in the traditional energy production sector due to the growth of the renewable sector is expected, and these workers will not necessarily be redirected to the renewable sector, but will more likely be employed in other sectors, thus a one to one replacement of jobs lost in fossil fuel-based energy by jobs gained in renewable energy activities is unlikely [58].

According to stakeholder interviews, an important step towards increasing public acceptance is to involve local people and cooperatives in all stages of project development. As an example, stakeholders referenced a solar park planned in the north of the Netherlands, developed without consulting the local population during project development, resulting in local resistance. This insights has been backed by research projects on the Dutch energy transition indicating that early engagement of stakeholders and even co-ownership increases the likelihood of public acceptance of projects under the low-emission energy transition [59-63]. In principle it would be easier to mount solar panels in the countryside, as developers only need to agree with the landowner, and it is easier to 'hide' and fit the park in the existing landscape, leading to lower public resistance risks. However, this may contradict regional regulations, for instance in the province of Fryslân, which prefers installing solar parks near cities and towns [64]. As a result, there is an ongoing political discussion on how to deal with land-use issues and different point of views between and lack of overarching visions on spatial planning of solar parks at the national, provincial and (local) government levels.

Along with local ownership, the Dutch NECP highlights a municipal focus also echoes findings from the literature which emphasize varying local motivations for support of RES. In some cases, the local population is able to invest in and benefit from nearby solar parks via crowd funding, purchase of certificates or obligations for a park, or postal code 'rose' regulation, through which citizens are able to invest in a nearby solar park and receive tax benefits on their electricity [65]. However, it is unclear whether citizens mainly take part in such projects for financial reasons, or because of the environmental benefits. It could be a motivating factor for people to be part of a decision-making process and feel that they contribute to societal and environmental improvements. This feeling may increase the more people become familiar with climate change impacts and needed solutions. In addition, people's feedback might improve the project design (aesthetics, location, etc.), likely increasing overall acceptance [39].

With respect to acceptance of rooftop PV, the idea of rooftop panels as status symbol, showing that the owner of the panels invested money (cost signalling) and cares about the environment, may increase acceptance. Another aspect is that of communication of all benefits of renewable energy technologies to households, i.e. environmental and social in addition to financial benefits. Financial incentives generally provide only a short-term solution, and should this incentive be taken away, interest in renewables may decline as households are insufficiently familiar with other environmental motivations [39].

\section{Discussion}

\section{Economic aspects}

The three cases demonstrate the impact of including integration costs into macroeconomic analyses of largescale RES build-up as planned in the NECPs. The Austrian and Greek cases highlight how similar economic impacts, and implications of integration costs, may arise in countries with wholly separate starting conditions: Greece with little RES penetration and high costs of capital, and Austria with ample RES and cheap capital.

The results illustrate the importance of understanding country contexts; for instance, the limited capital availability in Greece causes investments in capital-intensive renewable energy technologies to become relatively costly, eventually passed on to end users as higher electricity prices. Another example is Austria with its large share of hydroelectricity; as hydropower generally has relatively low operational costs, almost any investment in non-hydro low-emission technologies will cause electricity prices to go up, as the competitive level is relatively low already.

The cases have also made clear that scaling up a technology for mitigation does not mean simply implementing a single technology project multiple times within the country; while a single renewable project can be connected to the grid without causing stability issues, scaling up the technology to multiple projects may require extensive stability investments, as seen in the Netherlands case, with large economic impacts.

\section{Environmental effectiveness}

From an environmental perspective, scaling up lowemission energy technologies will contribute to achieving medium- to long-term climate goals and reaching targets of the Paris Agreement. Moreover, replacing fossil fuel-based technologies with renewable energy or 
other low-emission technology options will contribute to cleaner living environments and improved health conditions. However, the benefits - and accounting in GHG inventories - may be overstated, when one looks at lifecycle-based CPTs and how RES scale-up is planned in the NECPs. Greece, due to its southerly coastal location, would benefit from short CPTs for both PV and solar, while Austria conversely faces long CPTs due to low solar insolation and wind speed, exacerbated by the high RES share of current electricity generation. The Netherlands, which takes a more front-loaded approach to planned RES build-up, would avoid the bulk of their new capacity not being carbon neutral in CPT terms, with mainly a small share of new PV built later in the decade not yet being net neutral.

An interesting insight from the Commission's communication on the Winter Package is that a large share of the installed renewable energy technologies is produced in Europe. In CPT terms, this implies that GHG emissions caused by producing, e.g., a wind turbine will be accounted for in the GHG inventory of the Member State where the production takes place, whereas the emission reductions related to operating the turbine will accrue to the Member States which operate it. In other words, the CPT for this wind turbine is an indicator of how long it takes to offset life-cycle emissions by emission reductions caused by the same technology within Europe, even though these emission impacts appear in different Member States' INECPs and GHG inventories. Therefore, in these cases, the CPT indicator may not directly be determined at the level of individual Member States, but rather for the EU as a whole, and thus function as an indicator of climate effectiveness of mitigation options at the EU level.

\section{Social acceptance}

The three cases have highlighted a range of aspects related to social adoption and acceptance of technologies for mitigation in the Member States. Technologies' social implications can be broad, ranging from impacts on employment to changes in the landscape nearby residential cores. With respect to the latter, the cases have illustrated how gaining public acceptance of scaled up technologies can be a challenge under NECP development. The cases strongly point to issues with contextual factors; from Greek 'NIMBY' attitudes on wind parks to the lack of public knowledge and skills for energy efficiency, to other issues such as the structure of nationaland state-level authorities, and the powers and responsibilities delegated to them.

As shown by the Netherlands case, and reflected in its NECP, the close inclusion of stakeholders in planning and development stages of RES policy can have a positive effect on acceptance; conversely a feeling of a project being imposed upon them could give rise to feelings of discomfort and protest, especially when it is clearly visible and considered to be a disruption of the landscape (as is the opinion of wind farms in Greece). The Dutch case also shows that public buy-in (either literally via local ownership, or via project co-design) may enhance acceptance levels. While the Greek NECP also highlighted the need for projects with local value added, it is less clear (as reflected in the EC comments on draft NECPs) how extensive public engagement was in this regard, and the extent to which projects will have broad public acceptance in the future.

The Netherlands NECP emphasized exploring how plans fit within or competes with other activities in the areas concerned and who will be impacted. This 'areabased' innovation, preferably carried out at municipal and provincial levels, focuses on addressing a combination of issues at the same time (e.g., not only energy generation but also improving air quality, generating jobs, etc.), to balance multiple individual preferences within an energy transition package. Such inclusive processes may also imply more flexibility in terms of zone planning and choosing locations for project activities, and the approach of the Dutch NECP could provide a blueprint for the other cases or outside countries which were comparatively less extensive in addressing public acceptance.

\section{Conclusions}

In this work, the impacts of scaling up options for mitigation as spelled out in country NECPs have been assessed in further detail through case study analysis in three EU Member States: Austria, Greece and the Netherlands. These Member States have different characteristics in terms of, for instance, capacity and uptake of renewable energy, existing energy mix, as well as availability of capital for scaling up technology options. As final NECPs have been submitted to the EC by December 31st, 2019, our work assessed the NECPs under three broad criteria for policy success (i) economic efficiency, (ii) environmental effectiveness, (iii) feasibility, and highlighted remaining research gaps needing to be addressed as countries begin to implement their plans.

The three cases we assess provide examples of how the approaches within NECPs may be inadequately addressing the three criteria above. Plans should achieve objectives at the minimum cost to society, but large scale RES implementation - a major contribution to reducing GHG emissions - entails significant costs as demonstrated in our cases, which are not typically taken into consideration in current macroeconomic policy assessment and which may lead to over or underestimation of economic effects and subsequent inefficiencies in implementing policy. 
In terms of environmental effectiveness, plans should meet intended environmental objectives - in this case, GHG reduction targets set by the EU. However, without taking into account the life cycle emissions, and the fact that the emissions involved in pr5oduction and construction of RES may take place in other EU states or elsewhere, NECPs may be overstating their contribution to such goals. Under different measures of accounting (e.g. consumption-based), such emissions may be internalized, changing the resulting estimates of GHG reductions.

Finally, feasibility addresses the extent to which a policy is likely to gain acceptance; the NECPs of our cases varied widely in how they addressed public acceptance. While Greece indicated the need for projects with local value-added, and both Greece and Austria held stakeholder workshops and roundtables and allowed for public comment on draft NECPs, there is no indication that e.g. public sentiment is relatively negative to windfarms in Greece, or that conversely PV is more highly looked upon by the public, was taken into account. On the other hand, the Netherlands demonstrated in its NECP an extensive approach to public acceptance, which was noted by the EC in its review of the draft plan, in contrast to the other cases. The Dutch case focuses on producing plans which are acceptable at a municipal level via a number of pathways for community engagement and encouraging local acceptance, which could be used as a blueprint by other countries who now have to implement their plans.

The case study analysis in this paper has highlighted a range of aspects to be considered for integrated energy and climate planning, such as in the NECP context, all of which go far beyond evaluating a technology solely based on their production-based emissions. Instead, for finding optimal and costeffective solutions for electricity grid expansion under climate change policy in the EU, the apparent 'simple' solutions may not necessarily be the best for reducing emissions, and expansion of renewable technologies may be constrained by factors to which policy makers may have traditionally paid less attention.

\section{Abbreviations \\ NECP: National Climate and Energy Plan; GHG: Greenhouse gas; CGE: Computable General Equilibrium; CPT: Carbon payback time; RES: Renewable energy sources; PV: Photovoltaic; WACC: Weighted average cost of capital; LCOE: Levelized cost of electricity; GDP: Gross domestic product; CES: Constant elasticity of substitution; MWh: Megawatt hour; kW: Kilowatt hour; TWh: Terawatt hour; NIMBY: Not-In-My-Backyard; W/ $\mathrm{m}^{2}$ : Watts per square meter; $\mathrm{m} / \mathrm{s}$ : Meters per second}

\section{Acknowledgements}

We thank Sören Lindner and Heleen deConinck for their thoughtful inputs in the preparation of this work.

\section{Authors' contributions}

KW, GB and AT prepared the case studies on Austria and Greece, WG and KS prepared the case study on the Netherlands, KW, WG and GB wrote the manuscript. All authors read and approved the final manuscript.

\section{Funding}

The reported research was conducted as part of the CARISMA project, which received funding from the European Horizon 2020 programme of the EU under the Grant Agreement No. 642242.

\section{Availability of data and materials}

All data and results discussed in this work can be obtained by referring to the referenced sources (e.g. country National Energy and Climate Plans,

publications documenting economic analysis etc.) as they are noted in the text.

\section{Declarations}

Ethics approval and consent to participate

Not applicable.

\section{Consent for publication}

Not applicable.

\section{Competing interests}

The authors declare that they have no competing interests.

\section{Author details}

${ }^{1}$ Wegener Center for Climate and Global Change, University of Graz, Brandhofgasse 5, A-8010 Graz, Austria. ${ }^{2}$ JIN Climate and Sustainability, Ubbo Emmiussingel 19, 9711 BB Groningen, The Netherlands. ${ }^{3}$ LIFE - Institute for Climate, Energy and Society, Joanneum Research, Waagner-Biro-Straße 100, A-8020 Graz, Austria.

Received: 14 September 2018 Accepted: 20 February 2022

Published online: 07 March 2022

\section{References}

1. European Commission. Clean Energy For All Europeans. https://ec.europa. eu/energy/sites/ener/files/documents/com_860_final.pdf (2016).

2. European Commission Directorate-General for Energy, Clean energy for all Europeans package [WWW Document]. European Commission. 2019. https://energy.ec.europa.eu/topics/energy-strategy/clean-energy-all-europea ns-package_en. Accessed 28 Feb 2022.

3. Stavins $\mathrm{R}$, et al. In: Edenhofer $\mathrm{O}$, et al., editors. International Cooperation: Agreements \& Instruments. in Climate Change 2014: Mitigation of Climate Change. Contribution of Working Group III to the Fifth Assessment Report of the Intergovernmental Panel on Climate Change. Cambridge University Press; 2014.

4. Loriaux JM, Steinmann ZJN, Hanssen S, Daemen J, de Jonge M, Smits D, et al. Life-cycle assessments of climate mitigation technologies. Nijmegen, the Netherlands: Radboud University; 2016. (EU H2020 Project CARISMA).

5. Elliott RJR, Lindley JK. Environmental jobs and growth in the United States. Ecol Econ. 2017;132:232-44. https://doi.org/10.1016/j.ecolecon.2016.09.030.

6. Skoczkowski T, Bielecki S, Kochański M, Korczak K. Climate-change induced uncertainties, risks and opportunities for the coal-based region of Silesia: stakeholders' perspectives. Environ Innov Societal Transit. 2019:35:460-81. https://doi.org/10.1016/j.eist.2019.06.001.

7. Keramidas, K. et al. Global energy and climate outlook 2018: sectoral mitigation options towards a low-emissions economy - Global context to the EU strategy for long-term greenhouse gas emissions reduction. 2018. http://publications.europa.eu/publication/manifestation_identifier/PUB_ KJNA29462ENN

8. Hirth L, Ueckerdt F, Edenhofer O. Integration costs revisited - an economic framework for wind and solar variability. Renew Energy. 2015;74:925-39. https://doi.org/10.1016/j.renene.2014.08.065.

9. Best R. Switching towards coal or renewable energy? The effects of financial capital on energy transitions. Energy Econ. 2017;63:75-83.

10. Bachner G, Tuerk A, Williges K, Steininger KW. Economic Costs and Benefits of Renewables Deployment in the EU. Graz, Austria: University of Graz; 2017. (EU H2020 Project CARISMA).

11. Goulder LH, Parry IWH. Instrument Choice in Environmental Policy. https:/pa pers.ssrn.com/abstract=1117566; 2008. https:/doi.org/10.2139/ssrn.1117566. 
12. Stavins RN. Policy Instruments for Climate Change: How Can National Governments Address a Global Problem? vol. 39 http://www.rff.org/files/sha repoint/Worklmages/Download/RFF-DP-97-11.pdf; 1997.

13. Duval R. A Taxonomy of Instruments to Reduce Greenhouse Gas Emissions and Their Interactions. OECD Economics Department Working Paper No. 636. Organisation for Economic Co-operation and Development. 2008

14. Konidari P, Mavrakis D. A multi-criteria evaluation method for climate change mitigation policy instruments. Energy Policy. 2007;35(12):6235-57. https://doi.org/10.1016/j.enpol.2007.07.007.

15. Rey, L., Markandya, A., Gonzáles-Egiuno, M. \& Drummond, P. Assessing Interaction between instruments and the 'optimality' of the current instrument mix. http://cecilia2050.eu/system/files/Rey\%20et\%20al.\%20\%282 013\%29_Assessing\%20Interaction\%20between\%20instruments\%20and\%2 Othe\%20\%E2\%80\%98optimality\%E2\%80\%99\%20of\%20the\%20current\%2 Oinstrument\%20mix.pdf (2013).

16. Hood C. Summing Up the Parts: Combining Policy Instruments for LeastCost Climate Mitigation Strategies, vol. 72 http://www.iea.org/publications/ freepublications/publication/Summing_Up.pdf; 2011.

17. Görlach, B. What constitues an optimal policy mix? Defining the concept of optimality, including political and legal framework conditions. http://cecilia2 050.eu/system/files/G\%C3\%B6rlach\%20\%282013\%29_What\%2 Oconstitutes\%20an\%20optimal\%20policy\%20mix_0.pdf (2013).

18. Bößner S, de Coninck H. Report WP4.4: Report on lessons learned from technology assessment. Nimegen, the Netherlands: Radboud University; 2018. (EU H2020 Project CARISMA).

19. European Commission. 2019 EU report on policy coherence for development. https://ec.europa.eu/international-partnerships/system/files/ swd-2019-20-pcdreport_en.pdf. (2019).

20. Oikonomou V, Jepma CJ. A framework on interactions of climate and energy policy instruments. Mitig Adapt Strateg Glob Chang. 2007;13(2):13156. https://doi.org/10.1007/s11027-007-9082-9.

21. Bachner G, Steininger KW, Williges K, Tuerk A. The economy-wide effects of largescale renewable electricity expansion in Europe: the role of integration costs. Renew Energy. 2019;134:1369-80. https://doi.org/10.1016/j.renene.2018.09.052.

22. Eurostat. Share of energy from renewable sources [dataset]. 2020. [cited 2020 Feb 28] European Commission - EurostatUnit 5: Energy. Available from: https:/appsso. eurostat.ec.europa.eu/nui/show.do?dataset=nrg_ind_ren\&lang=en.

23. Ministry of the Environment and Energy - Hellenic Republic. National Energy and Climate Plan. https://ec.europa.eu/energy/sites/ener/files/el_fina I_necp_main_en.pdf (2019).

24. European Commission. Assessment of the National Energy and Climate Plan of Greece. Brussels, Belgium: European Commission; 2019 Jun. Report No.: C(2019) 4408.

25. Eurostat. Wind and water provide most renewable electricity [Internet]. Eurostat News. 2020 [cited 2020 Mar 28]. Available from: https://ec.europa. eu/eurostat/web/products-eurostat-news/-/DDN-20200129-1.

26. Federal Ministry of Sustainability and Tourism. Integrated national energy and climate plan for Austria. https://ec.europa.eu/energy/sites/ener/files/ documents/at_final_necp_main_en.pdf (2019).

27. European Commission. Assessment of the draft National Energy and Climate Plan of Austria. Brussels, Belgium: European Commission; 2019 Jun. Report No:: C(2019) 4420.

28. Kirchengast, G. et al. Referenzplan als Grundlage für einen wissenschaftlich fundierten und mit den Pariser Klimazielen in Einklang stehenden Nationalen Energie- und Klimaplan für Österreich (Ref-NEKP) Vision 2050 und Umsetzungspfade: Österreich im Einklang mit den Pariser Klimazielen und der Weg dorthin. ISBN 1-30 (2020) https://doi.org/10.1553/Ref-NEKP-Vision2050s1.

29. European Commission. 2020 by 2020: Europe's climate change opportunity. Brussels, Belgium: European Commission; 2008 Jan. Report No.: COM(2008) 30.

30. Ministry of Economic Affairs and Climate Policy. Integrated National Energy and Climate Plan 2021-2030 [Internet]. The Netherlands; 2019 Nov [cited 2022 Feb 28]. Available from: https://ec.europa.eu/energy/sites/ener/files/ documents/nl_final_necp_main_en.pdf.

31. European Commission. Assessment of the National Energy and Climate Plan of the Netherlands. Brussels, Belgium: European Commission; 2019 Jun. Report No.: C(2019) 4419.

32. Pollitt H, Lewney R, Mercure J-F. Conceptual differences between macroeconometric and CGE models. In: 27th International Input-Output Association Conference [Internet]. Glasgow, Scotland; 2019 [cited 2022 Feb 28]. Available from: https://www.iioa.org/conferences/27th/papers/files/3 597_20190430081_IIOApaperE3MEsession.pdf.
33. Ondraczek J, Komendantova N, Patt A. WACC the dog: the effect of financing costs on the levelized cost of solar PV power. Renew Energy. 2015;75:888-98. https://doi.org/10.1016/j.renene.2014.10.053.

34. Böhringer, C., Rutherford, T. F. \& Wiegard, W. Computable General Equilibrium Analysis: Opening a Black Box. http://ub-madoc.bib.uni-ma nnheim.de/363 (2004).

35. Aguiar A, Narayanan B, McDougall R. An overview of the GTAP 9 Data Base. J Glob Econ Anal. 2016;1(1):181-208. https://doi.org/10.21642/JGEA.010103AF.

36. Carrara S, Marangoni G. Including system integration of variable renewable energies in a constant elasticity of substitution framework: the case of the WITCH model. Energy Econ. 2016;64:612-26. https://doi.org/10.1016/j. eneco.2016.08.017.

37. Hirth L. Market value of solar power: is photovoltaics cost-competitive? IET Renew Power Gener. 2015;9(1):37-45. https://doi.org/10.1049/iet-rpg.2014.0101.

38. Hirth $L$. The market value of variable renewables: the effect of solar wind power variability on their relative price. Energy Econ. 2013;38:218-36. https://doi.org/10.1016/j.eneco.2013.02.004.

39. Mayer J, van der Gaast W, Bachner G, Spijker E. Qualitative and quantitative risk assessment of expanding photovoltaics in the Netherlands. Environ Innov Societal Transit. 2019;35:357-68. https://doi.org/10.1016/j.eist.2019.10.010.

40. Mayer J, Bachner G, Steininger KW. Macroeconomic implications of switching to process-emission-free iron and steel production in Europe. J Clean Prod. 2019;210:1517-33. https://doi.org/10.1016/j.jclepro.2018.11.118.

41. Bachner G, Wolkinger B, Mayer J, Tuerk A, Steininger KW. Risk assessment of the low-carbon transition of Austria's steel and electricity sectors. Environ Innov Societal Transit. 2018;35:309-32. https://doi.org/10.1016/j.eist.2018.12.005.

42. Abeliotis K, Pactiti D. Assessment of the environmental impacts of a wind farm in Central Greece during its life cycle. Int J Renew Energy Res (IJRER). 2014:4:580-5.

43. Schinko T, Komendantova N. De-risking investment into concentrated solar power in North Africa: impacts on the costs of electricity generation. Renew Energy. 2016:92:262-72. https://doi.org/10.1016/.renene.2016.02.009.

44. Komendantova N, Schinko T, Patt A. De-risking policies as a substantial determinant of climate change mitigation costs in developing countries: case study of the Middle East and north African region. Energy Policy. 2019; 127:404-11. https://doi.org/10.1016/j.enpol.2018.12.023.

45. Bachner G, Mayer J, Steininger KW. Costs or benefits? Assessing the economy-wide effects of the electricity sector's low carbon transition - the role of capital costs, divergent risk perceptions and premiums. Energy Strateg Rev. 2019;26:100373. https://doi.org/10.1016/j.esr.2019.100373.

46. PBL. Klimaat- en Energieverkenning 2019. PBL Planbureau voor de Leefomgeving https://www.pbl.nl/publicaties/klimaat-enenergieverkenning-2019 (2019)

47. Makrides G, Zinsser B, Georghiou GE, Schubert M, Werner JH. Outdoor efficiency of different photovoltaic systems installed in Cyprus and Germany. In: 2008 33rd IEEE Photovoltaic Specialists Conference. 2008. p. 1-6.

48. DTU Wind Energy. Global Wind Atlas [dataset]. 2017 [cited 2022 Feb 28]. Technical University of Denmark (DTU). Available from: https:/globalwindatlas.info/.

49. Kaldellis JK, Kapsali M. Kaldelli, El. \& Katsanou, Ev. Comparing recent views of public attitude on wind energy, photovoltaic and small hydro applications. Renew Energy. 2013;52:197-208. https://doi.org/10.1016/j.renene.2012.10.045.

50. Kontogianni A, Tourkolias Ch, Skourtos M, Damigos D. Planning globally, protesting locally: Patterns in community perceptions towards the installation of wind farms. Renewable Energy. 2014;66:170-7.

51. Apostol D, Palmer J, Pasqualetti M, Smardon R, Sullivan R. The Renewable Energy Landscape: Preserving Scenic Values in Our Sustainable Future: Taylor \& Francis; 2016.

52. Kaldellis JK, Kapsali M, Katsanou E. Renewable energy applications in Greece-what is the public attitude? Energy Policy. 2012;42:37-48. https:// doi.org/10.1016/j.enpol.2011.11.017

53. Fruhmann C, Tuerk A, Kulmer V, Gubina AF. Balancing environmental benefits and damages of small hydropower generation in policy-making: assessing the implementation of a contradicting EU policy framework in Austria and Slovenia. International Journal of Sustainable Energy. 2019:38(1):37-49.

54. Walter G, Gutscher H. Public acceptance of wind energy and bioenergy projects in the framework of distributive and procedural justice theories: insights from Germany, Austria and Switzerland; 2010.

55. Steurer R, Clar C, Casado-Asensio J. Climate change mitigation in Austria and Switzerland: the pitfalls of federalism in greening decentralized building policies. Nat Res Forum. 2020;44(1):89-108. https://doi.org/10.1111/1477-894 7.12166 . 
56. Koning M, Smit N, van Dril T. Energieakkoord - Effecten van de energietransitie op de inzet en kwaliteit van arbeid. [Internet]. Economisch Instituut voor de Bouw; 2016. Available from: https://publications.tno.nl/ publication/34632350/9q5k2Z/016050.pdf.

57. Ligtvoet A, Pickles A, Barneveld J v. Kwalitatieve impact van het Energieakkoord op werkgelegenheid [Internet]. Technopolis group; 2016 [cited 2022 Feb 28]. Available from: https://www.topsectorenergie.nl/sites/ default/files/uploads/Algemeen/Eindrapport_Kwalitatieve_impact_Energiea kkoord_op_werkgelegenheid\%5B1\%5D.pdf.

58. Weterings A, Ivanova O, Diodato D, Lankhuizen M, Thissen M., Schure K, et al. Effects of the energy transition in regional labour markets - a quick scan. PBL Netherlands Environmental Assessment Agency; 2018. Report No.: PBL-issue 3006.

59. Liu L, Bouman T, Perlaviciute G, Steg L. Effects of trust and public participation on acceptability of renewable energy projects in the Netherlands and China. Energy Research \& Social Science. 2019;53:137-44. https://doi.org/10.1016/j.erss.2019.03.006.

60. Bijvoet TN. Shared ownership between energy cooperations and commercial investors in renewable energy projects [Master thesis]. Utrecht, the Netherlands: Utrecht University; 2018.

61. Akerboom S. Between public participation and energy transition: The case of wind farms [Internet] [PhD thesis]. Amsterdam, the Netherlands: University of Amsterdam; 2018 [cited 2020 Mar 28]. Available from: https:// dare.uva.nl/search?identifier=4198a137-4c34-4b65-a442-a10387e60a62.

62. Rooijers F, Kerkhoven J, den Ouden B. Noodzakelijk beleid Klimaatakkoord: Een maatschappelijke afweging [lnternet]. Delft, the Netherlands: CE Delft, Kalavasta, Berenschot; 2018 Nov [cited 2022 Feb 28]. Report No: 18.180008 152. Available from: https://ce.nl/wp-content/uploads/2021/03/CE_Delft_1 80008_Noodzakelijk_beleid_Klimaatakkoord.pdf.

63. de Coninck H, Revi A, Babiker M, Bertoldi P, Buckeridge M, Cartwright A, et al. Strengthening and Implementing the Global Response. In: MassonDelmotte V, Zhai P, Pörtner H-O, Roberts D, Skea J, Shukla PR, et al., editors. Global Warming of $15^{\circ} \mathrm{C}$ An IPCC Special Report on the impacts of global warming of $15^{\circ} \mathrm{C}$ above pre-industrial levels and related global greenhouse gas emission pathways, in the context of strengthening the global response to the threat of climate change, sustainable development, and efforts to eradicate poverty. In Press; 2018.

64. Gemeente Súdwest-Fryslân. Ruimte voor de zon [Internet]. 2015 [cited 2018 Aug 14]. Available from: http://www.topentwelonline.nl/uploads/Dorpsbela ng/notitie\%20Ruimte\%20voor\%20de\%20zon\%20college12-7.pdf.

65. DNV GL. Nationaal Actieplan Zonnestroom 2016 - op weg naar 10 GWp zonnenstroom in Nederland in 2023. Arnhem, the Netherlands: DNV GL; 2016.

\section{Publisher's Note}

Springer Nature remains neutral with regard to jurisdictional claims in published maps and institutional affiliations.

Ready to submit your research? Choose BMC and benefit from:

- fast, convenient online submission

- thorough peer review by experienced researchers in your field

- rapid publication on acceptance

- support for research data, including large and complex data types

- gold Open Access which fosters wider collaboration and increased citations

- maximum visibility for your research: over $100 \mathrm{M}$ website views per year

At $\mathrm{BMC}$, research is always in progress.

Learn more biomedcentral.com/submissions 